\title{
A Novel Coumarin-Based Fluorescent Probe With Aggregation Induced Emission for Detecting Cn- and Its Applications in Bioimaging
}

\section{Sha Deng}

Nanjing Normal University

Qiao Lei

Nanjing Normal University

Junzhe Cai

Nanjing Normal University

Yuliang Jiang ( $D$ 07205@njnu.edu.cn )

Nanjing Normal University https://orcid.org/0000-0002-9037-2080

Jian Shen

Nanjing Normal University

\section{Research Article}

Keywords: Cyanogen ion, Aggregation-induced emission, Excited state intramolecular proton transfer, Imaging, Zebrafish

Posted Date: July 7th, 2021

DOl: https://doi.org/10.21203/rs.3.rs-641968/v1

License: (c) (i) This work is licensed under a Creative Commons Attribution 4.0 International License. Read Full License 


\section{Abstract}

Although cyanogen ion $\left(\mathrm{CN}^{-}\right)$plays important role in industry which also bring acute environmental pollution. More serious, trace $\mathrm{CN}^{-}$enters the human body can cause serious consequences and even death. Therefore, it is of great significance to detect trace $\mathrm{CN}^{-}$with high sensitivity. Herein, a novel aggregation-induced emission (AIE) probe $\mathrm{C}-\mathrm{BH}$ was synthesized based on coumarin matrix. Probe $\mathrm{C}-\mathrm{BH}$ showed high selectivity and sensitivity toward $\mathrm{CN}^{-}$by dual channel response due to the excited state intramolecular proton transfer (ESIPT). The low detection limit was calculated to be $0.05 \mu \mathrm{M}$. Moreover, probe $\mathrm{C}-\mathrm{BH}$ was successfully used for imaging $\mathrm{CN}^{-}$in living cells and zebrafish due to its low toxicity and excellent optical properties.

\section{Introduction}

Cyanogen ion $\left(\mathrm{CN}^{-}\right)$is notorious for its strong toxicity [1]. As we know, trace $\mathrm{CN}^{-}$can cause serious damage to the central nervous system by combining with $\mathrm{Fe}^{3+}$ of heme unit in hemoglobin [2]. Generally speaking, the concentration of $\mathrm{CN}^{-}$in blood should be less than $20 \mu \mathrm{M}$ to ensure the safety of organism, excessive $\mathrm{CN}^{-}$may trigger serious adverse physiological reactions and lead to death [3-5]. Therefore, accurate detection of $\mathrm{CN}^{-}$concentration in living organisms is of great significance to maintain the vitality of living organisms. So far, different analytical such as high performance liquid chromatography, mass spectrometry, inductively coupled plasma atomic emission spectrometry, and atomic absorption spectroscopy were exploited for monitoring $\mathrm{CN}^{-}$

*Corresponding authors.

E-mail address: 07205@njnu.edu.cn (Y.L. Jiang); jshen_njnu@163.com(J. Shen)

and made some progress [6-10]. However, some defects such as high expenses, time-consuming and complicated operations made these measurement not easy to promote. It is urgent for developing new detection methods to overcome these defects and realize simple, rapid and high sensitivity detection of trace $\mathrm{CN}^{-}$.

In recent decades, fluorescence analysis has proved to be an important detection method in the field of life science due to its advantages in simple operation, non-destructive and rapid detection [11-15]. Fluorescence analysis was applied to the determination of $\mathrm{CN}^{-}$in living organisms can effectively solve the difficulties as above mentioned. So far, only a few $\mathrm{CN}^{-}$fluorescent probes were reported and most of them were single channel detection which easy to be affected by environment and instrument background. As we know, one probe possess ESIPT features can not only provide large Stoke shift to avoid the influence of fluorescence self-absorption, but also offer dual channel detection which makes fluorescence detection more accurate and effective [16-20]. In view of the toxicity of trace $\mathrm{CN}^{-}$, 
construction of dual channel probe for detection of $\mathrm{CN}^{-}$could provide a built-in correction and thus make the analysis more accurate.

Since the discovery of AIE phenomenon by Tang's Group in 2001, a large number of AIE-gens fluorescent probes have been developed which expanded the application in biological system greatly [21-24].

However, AlE probes were rarely used in cyanide detection which were not conducive to the development of this field, so it is necessary to develop AIE probes for the detection of $\mathrm{CN}^{-}$. In addition, as a kind of natural products, coumarin has excellent photoelectric and low toxicity which can be used in photoelectric materials, sensors and bioimaging field. Based on the above considerations, in this paper, coumarin was selected as fluorescent matrix through Schiff base reaction, a novel fluorescent probe C-BH with AIE properties was obtained which showed "switch-on" phenomenon to $\mathrm{CN}^{-}$with high selectivity, high sensitivity and low detection.

\section{Experimental Section}

\subsection{Materials and Methods}

Unless otherwise specified, all reagents are purchased from commercial suppliers and without further purification is required for use. 7-Hydroxy-4-methyl-2H-chromen-2-one, hexamethylenete tramine, acetic acid, benzophenone hydrazone, hydrochloric acid and ether was obtained from Adamas-beta ${ }^{\circledR}$ (Shanghai, China). ${ }^{1} \mathrm{H}$ NMR and ${ }^{13} \mathrm{C}$ NMR experiments were performed with an AVANCE III HD AN-400 $\mathrm{MHz}$ spectrometer (Bruker, Germany). Mass spectra were recorded on a LCMS-2020 spectrometer (Shimadzu, Japan). UV-vis spectra were recorded on a Perkin Elmer Lambda 1050 + spectrometer (PerkinElmer, USA). Fluorescence spectra were measured on a PE LSS55 fluorescence spectrophotometer (PerkinElmer, USA). The fluorescence imaging experiment was carried out on the A1 confocal laser scanning microscope (Nikon, Japan).

\subsection{Synthesis of C-BH}

The synthetic route for preparing probe $\mathrm{C}-\mathrm{BH}$ is given in scheme 1 . The intermediate 1 was synthesized according to the previous report [25]. Probe $\mathrm{C}-\mathrm{BH}$ was obtained by simple preparation. Briefly, a mixture of the intermediate $1(0.1632 \mathrm{~g}, 0.8 \mathrm{mmol})$ and benzophenone hydrazone $(0.1963 \mathrm{~g}, 1 \mathrm{mmol})$ was dissolved in ethanol $(25 \mathrm{~mL})$. A drop of acetic acid was added and the mixture was refluxed for 6 hours. The orange solid was precipitated, cooled, filtered and washed with cold ethanol to obtain the product $(0.25 \mathrm{~g}$, yield: 81.8\%). ${ }^{1} \mathrm{H}$ NMR (400 MHz, DMSO- $\left.d_{6}\right) \delta 12.05(\mathrm{~s}, 1 \mathrm{H}), 9.20(\mathrm{~s}, 1 \mathrm{H}), 7.70(\mathrm{t}, J=8.1 \mathrm{~Hz}, 3 \mathrm{H}), 7.62-7.44(\mathrm{~m}$, $6 \mathrm{H}), 7.32(\mathrm{dd}, J=6.7,3.0 \mathrm{~Hz}, 2 \mathrm{H}), 6.78(\mathrm{~d}, J=8.9 \mathrm{~Hz}, 1 \mathrm{H}), 6.24(\mathrm{~s}, 1 \mathrm{H}), 2.36(\mathrm{~s}, 3 \mathrm{H}) .{ }^{13} \mathrm{C} \mathrm{NMR}(101 \mathrm{MHz}$, DMSO- $\left.d_{6}\right) \delta 169.45,162.63,159.49,158.18,154.32,153.84,136.61,135.54,132.02,130.53,129.77$, 129.26, 129.21, 129.17, 128.51, 113.72, 112.22, 111.31, 105.72, 18.80. ESI-MS m/z: [probe] ${ }^{-}$calcd for $\mathrm{C}_{24} \mathrm{H}_{20} \mathrm{~N}_{2} \mathrm{O}_{3} 381.13$; Found 381.20. The Correlation spectrum were showed in Figure S1-S3.

\subsection{Optical measurements}


Stock solutions of probe C-BH (10 mM) was prepared in DMSO solution. In addition, $\mathrm{Ag}^{+}, \mathrm{Co}^{2+}, \mathrm{Fe}^{3+}, \mathrm{Cr}^{3+}$, $\mathrm{Pb}^{2+}, \mathrm{Zn}^{2+}, \mathrm{Cys}, \mathrm{CH}_{3} \mathrm{COO}^{-}, \mathrm{Cl}^{-}, \mathrm{NO}_{2}{ }^{-}, \mathrm{NO}_{3}{ }^{-}, \mathrm{H}_{2} \mathrm{PO}_{4}{ }^{-}$were prepared in distilled water from their corresponding salts, respectively. The fluorescent and absorption changes were recorded at room temperature each time.

\subsection{Cell Culture}

The HeLa cells were grown at $37^{\circ} \mathrm{C}$ in a humidified $5 \% \mathrm{CO}_{2}$ incubator using DMEM (Dulbecco's modified eagle's medium) supplemented with $10 \%$ (v/v) FBS (fetal bovine serum) for $24 \mathrm{~h}$. Four groups of cells were studied. One group cell was incubated with probe $\mathrm{C}-\mathrm{BH}(10 \mu \mathrm{M})$ and used as control group, the other three groups were treated with different concentrations of $\mathrm{CN}^{-}(5,10$ and $15 \mu \mathrm{M})$ after incubated with probe C-BH for another $30 \mathrm{~min}$.

\subsection{Fluorescence imaging in zebrafish}

Zebrafish research was approved by the NNU animal ethics and welfare Commission and was conducted in accordance with the European guidelines for the care and use of laboratory animals. Zebrafish is provided by Shanghai FishBio Co., Ltd. 5-day-old zebrafish was incubated with $10 \mu \mathrm{M}$ the probe C-BH for $0.5 \mathrm{~h}$. After removing the excess probe with PBS, zebrafish were further treated with $\mathrm{CN}^{-}(5,10,15 \mu \mathrm{M})$ for 30 minutes. The zebrafish were only treated with probe $\mathrm{C}-\mathrm{BH}(10 \mu \mathrm{M})$ was used as the control group. The imaging was performed in the green channel $(488 \mathrm{~nm})$ and blue channel $(405 \mathrm{~nm})$.

\section{Results And Discussion}

\subsection{Synthesis of probe $\mathrm{C}-\mathrm{BH}$}

As a kind of excellent fluorescent matrix, coumarin received much attention and have been used in sensor field widely [26-29]. In this paper, coumarin was selected as fluorescent parent, benzophenone hydrazone was introduced by Schiff base reaction for giving probe $\mathrm{C}-\mathrm{BH}$ with high yields. The formed " $\mathrm{C}=\mathrm{N}$ " not only endows probe $\mathrm{C}-\mathrm{BH}$ with tetrastyrene like structure and engendered AIE properties, it also can be used as the action site of $\mathrm{CN}^{-}$which realized the original intention of the design.

\subsection{AIE properties}

With probe C-BH in hand, we first evaluated the AIE performance of the probe C-BH in DMSO and $\mathrm{H}_{2} \mathrm{O}$ mixtures with different water fractions. The result was showed in Fig. 1a, probe C-BH showed weak fluorescence when the proportion of $\mathrm{H}_{2} \mathrm{O}$ is less than $50 \%$, with the increase of water content, the fluorescence intensity of probe $\mathrm{C}$-BH synchronous enhancement. The fluorescence intensity reaches the maximum when the water content reached $85 \%$ and showed strong yellow fluorescence. Scale diagram of fluorescence peak intensity and ratio of water was exhibited in Fig. 1b. The molecular aggregation morphology was further characterized by scanning electron microscopy (SEM), probe C-BH was dissolved in DMSO and DMSO / $\mathrm{H}_{2} \mathrm{O}(=1: 4 \mathrm{Vol})$ respectively. Dispersed spherical particles can be observed when the probe C-BH was dispersed in pure DMSO solution(Fig. S4a)while the solution was changed to 
DMSO $/ \mathrm{H}_{2} \mathrm{O}$, obvious accumulation of particles were appeared $[\mathrm{Fig}$. S4b $\square$ which proved probe $\mathrm{C}-\mathrm{BH}$ has AIE feature.

\subsection{Spectral properties}

UV-vis absorption spectrum of probe $\mathrm{C}-\mathrm{BH}$ was further researched, in the absent of $\mathrm{CN}^{-}$, probe $\mathrm{C}-\mathrm{BH}$ showed a single absorption peak at $325 \mathrm{~nm}$, while $60 \mu \mathrm{M} \mathrm{CN}^{-}$was added, the peak located at $325 \mathrm{~nm}$ was disappeared and two new peaks at 310 and $385 \mathrm{~nm}$ can be observed(Figure S5). As we know, probe $\mathrm{C}-\mathrm{BH}$ can act with $\mathrm{CN}^{-}$and causes the destruction of conjugate structure which result to blue shift of Ultraviolet spectrum. Meanwhile, the addition product of $\mathrm{CN}^{-}$and probe $\mathrm{C}-\mathrm{BH}$ can act with hydroxyl group of coumarin ring which produce ESIPT, and a new absorption peak at $385 \mathrm{~nm}$, the color change of the solution can be observed by naked eyes. Fluorescence spectrum of probe C-BH exhibited a peak at 563 $\mathrm{nm}$, the Stokes shift was calculated as $238 \mathrm{~nm}$ (Figure S6), as we know, such a large Stokes shift have never reported in the field of $\mathrm{CN}^{-}$probe. Subsequently, fluorescence titration experiment was carried out for evaluating the ability of the probe to recognize $\mathrm{CN}^{-}$, as showed in Fig. 2a, the solution of the probe C$\mathrm{BH}$ showed strong fluorescence at $563 \mathrm{~nm}$, with the added of $\mathrm{CN}^{-}$from 0-60 $\mu \mathrm{M}$, the fluorescence peak at $563 \mathrm{~nm}$ almost decreased gradually while a new peak located $440 \mathrm{~nm}$ was appeared and increased gradually. At $440 \mathrm{~nm}$, the relationship between fluorescence intensity and $\mathrm{CN}^{-}$can be described by the following linear equation: $Y=135.39 X+777.40, R^{2}=0.99$ (Fig. $2 b$ ), the detection limit $(3 \sigma)$ was determined to be $0.05 \mu \mathrm{M}(\mathrm{S} / \mathrm{N}=3)$. At $563 \mathrm{~nm}$, the relationship between fluorescence intensity and $\mathrm{CN}^{-}$ can be described by the logarithmic equation $Y=1865.98-384.94 \ln (x-3.88), R^{2}=0.95$ (Fig. 2c). In addition, the relationship between $\mathrm{CN}^{-}$concentration and $\mathrm{I}_{440 \mathrm{~nm}} / \mathrm{I}_{563 \mathrm{~nm}}$ ratio was further to be calculated and the result was showed in Fig. $2 d$, the ratio of $I_{440} \mathrm{~nm}$ to $I_{563} \mathrm{~nm}$ showed a good linear relationship in the concentration range of $0-60 \mu \mathrm{M}, \mathrm{Y}=0.3374 \mathrm{X}-0.7975, \mathrm{R}^{2}=0.99$. These data fully confirm that probe $\mathrm{C}-\mathrm{BH}$ can detect $\mathrm{CN}^{-}$effectively with a good linear relationship. Compared with reported probes, C-BH showed great advantages (Table 1) [4, 5, 30-32] which can be applied to the detection of trace $\mathrm{CN}^{-}$with high sensitive. 
Table 1

The comparison of $\mathrm{C}-\mathrm{BH}$ with the reported probes for sensing of $\mathrm{CN}^{-}$

\begin{tabular}{|llll|}
\hline Probe & $\begin{array}{l}\text { Detection } \\
\text { limit }(\mu \mathrm{M})\end{array}$ & Cell imaging & Ref. \\
\hline NPC & 0.145 & Yes & 4 \\
\hline TPA-BTD-MT & 0.087 & Yes & 5 \\
\hline P1 & 0.75 & No & 30 \\
\hline L1 & 1.1 & No & 31 \\
\hline Sensor 1 & 0.03 & Yes & 32 \\
\hline C-BH & 0.05 & Yes & This work \\
\hline
\end{tabular}

\subsection{Selectivity}

Considering that the ultimate application of probe is biological system, it is necessary to evaluate the effect of different interferences in biological system. Herein, various spices such as $\mathrm{Cu}^{2+}, \mathrm{Ni}^{2+}, \mathrm{Fe}^{3+}, \mathrm{GSH}$, Hcy, Cys, $\mathrm{H}_{2} \mathrm{O}_{2}, \mathrm{CH}_{3} \mathrm{COO}^{-}, \mathrm{Cl}^{-}, \mathrm{S}^{2-}, \mathrm{NO}_{2}{ }^{-}, \mathrm{S}_{2} \mathrm{O}_{3}{ }^{2-}, \mathrm{HSO}_{4}{ }^{-}(60 \mu \mathrm{M})$ were assessed under the same test conditions. The result was showed in Fig. 3 , only $\mathrm{CN}^{-}$can trigger violent fluorescence change while none of the selected species candidates caused obvious changes which demonstrated that our probe $\mathrm{C}-\mathrm{BH}$ exhibited higher selectivity and reliability towards $\mathrm{CN}^{-}$detection in complex organisms.

\subsection{The response time and $\mathrm{pH}$ of $\mathrm{C}-\mathrm{BH}$ to $\mathrm{CN}^{-}$}

The time dependence of the fluorescence of probe $\mathrm{C}-\mathrm{BH}$ toward $\mathrm{CN}^{-}$was investigated. Free probe $\mathrm{C}-\mathrm{BH}$ showed strong stability while $60 \mu \mathrm{M} \mathrm{CN}^{-}$was added, the fluorescence intensity at $440 \mathrm{~nm}$ was significantly enhanced within seconds and stable in about 20 minutes (Fig. 4a). In order to explore the application of the probe $\mathrm{C}-\mathrm{BH}$ under physiological conditions, the effect of $\mathrm{pH}$ on the fluorescence properties was evaluated, the result was showed in Fig. 4b, probe $\mathrm{C}-\mathrm{BH}$ showed stable fluorescence in the $\mathrm{pH}$ range of 2-10 and $\mathrm{C}-\mathrm{BH}-\mathrm{CN}^{-}$showed stable fluorescence in the $\mathrm{pH}$ range of $3-10$, indicating probe $\mathrm{C}$ $\mathrm{BH}$ can detect $\mathrm{CN}^{-}$in the life system.

\subsection{Mechanism description}

As we know, $\mathrm{CN}^{-}$can act with $\mathrm{C}=\mathrm{N}$ bond and formation of cyano substituted products which was mentioned in the previous report [31]. In this study, the reaction mechanism can be described as follows: in the presence of $\mathrm{CN}^{-}$, the $\mathrm{C}=\mathrm{N}$ bond of probe $\mathrm{C}-\mathrm{BH}$ was destroyed and give cyano substituted product which was confirmed by using MS analysis data ( $\mathrm{m} / \mathrm{z}=408.2 \mathrm{Fig}$. $\mathrm{S} 7)$. The specific mechanism was shown in Scheme 2. 


\subsection{Theoretical calculation}

In order to further study the interaction mechanism between the probe $\mathrm{C}-\mathrm{BH}$ and $\mathrm{CN}^{-}$. Density functional theory (DFT) calculation was performed at the B3LYP level of the Gauss09 program to understand their electronic structure. Figure 5 showed the optimized geometric configurations of $\mathrm{C}-\mathrm{BH}$ and $\mathrm{C}-\mathrm{BH}-\mathrm{CN}$ and their HOMOs and LUMOs. The energy gaps between HOMOs and LUMOs of C-BH and C-BH-CN were calculated to be $1.5792 \mathrm{eV}$ and $3.5178 \mathrm{eV}$ respectively. In the presence of $\mathrm{CN}^{-}$, the increased energy gap between the HOMO and LUMO is responsible for the blue-shift emission, which was consistent with the experimental results of ultraviolet and fluorescence spectrum.

\subsection{MTT assay and cellular imaging}

Better optical properties based on probe $\mathrm{C}-\mathrm{BH}$, we further explore its application in biology. First, the toxicity of C-BH against HeLa cells should be estimated by using the MTT assay. The suspension of HeLa cells cultured in a cell incubator for $24 \mathrm{~h}$. various concentrations of C-BH $(0,20,40,60,80$ and 100 $\mu \mathrm{M}$ ) were added and cultured in the cell incubator for another $24 \mathrm{~h}$. The results showed in Figure S8, Hela cell viability is still around $92 \%$ after treatment with $100 \mu \mathrm{M}$ of the probe $\mathrm{C}-\mathrm{BH}$ which illustrated that the toxicity of probe $\mathrm{C}-\mathrm{BH}$ is very low and very suitable for cell application.

We further investigated the application of the probe for $\mathrm{CN}^{-}$imaging in living cells. Four groups of HeLa cells were prepared, the first group of HeLa cells were pre-treated with the probe $\mathrm{C}-\mathrm{BH}(10 \mu \mathrm{M})$ solution for 30 min, the other three groups were added with different concentrations of $\mathrm{CN}^{-}(5,10,15 \mu \mathrm{M})$ and Incubated for further $30 \mathrm{~min}$, washed three times with PBS buffer solution before imaging by laser confocal microscopy. The result was illustrated in Fig. 6, HeLa cells were pre-treated with the probe C-BH showed weak green fluorescence, with the increased of $\mathrm{CN}^{-}$, the fluorescence of green channel was further weakened while the fluorescence of blue channel was appeared and gradually enhanced which implied the probe $\mathrm{C}-\mathrm{BH}$ can detect $\mathrm{CN}^{-}$by two channels increased the reliability of detection in biological system.

\subsection{Zebrafish imaging}

Considering the successful application of probe $\mathrm{C}-\mathrm{BH}$ in cells, in order to expand its application scope, we further explored the application of probe $\mathrm{C}-\mathrm{BH}$ in vivo. Zebrafish embryos ( 5 days old) were chosen as the animal model. Four groups of zebrafish were prepared. The first group of zebrafish were incubated with probe $\mathrm{C}-\mathrm{BH}(10 \mu \mathrm{M})$ for $0.5 \mathrm{~h}$, then used for fluorescence imaging. Weak green fluorescence can be observed, while the other three groups were further interacted with various $\mathrm{CN}^{-}(5,10,15 \mu \mathrm{M})$ for another $0.5 \mathrm{~h}$ after incubation with the probe $\mathrm{C}-\mathrm{BH}$. As Fig. 7 showed, with the increase of $\mathrm{CN}^{-}$, the green fluorescence almost completely quenched, and the blue channel fluorescence appeared and gradually enhanced which indicating that our probe $\mathrm{C}-\mathrm{BH}$ can be used to detect $\mathrm{CN}^{-}$in zebrafish. 


\section{Conclusions}

In summary, a novel AlE-gens fluorescent probe $\mathrm{C}-\mathrm{BH}$ was designed and synthetized rationally. Probe C$\mathrm{BH}$ showed good selectivity, high sensitivity and dual channel detected to $\mathrm{CN}^{-}$, the obvious fluorescence changes can be recognized by naked eyes. Due to its good optical properties, probe $\mathrm{C}$-BH has been applied to the detection of $\mathrm{CN}^{-}$in living cells and zebrafish successfully. This study provides a ratio fluorescent probe for monitoring $\mathrm{CN}^{-}$which is helpful for the early diagnosis of diseases caused by its abnormal level.

\section{Declarations}

Acknowledgements Dr. YL Jiang gratefully acknowledged the financial support of the China Postdoctoral Fund Surface Project (2017M610335), and a Project Funded by the Priority Academic Program Development of Jiangsu Higher Education Institutions (PAPD).

Author Statement YL Jiang provided the initial idea for this work; S Deng, Q Lei and JZ Cai contributed to the collection and analysis of test data; and S Deng contributed to the theoretical calculation. YL Jiang and $\mathrm{J}$ Shen contributed to the analyses of results; YL Jiang wrote the paper.

Compliance with ethical standards Zebrafish studies were approved by the Ethics Committee and IACUC of Qilu Health Science Center, Nanjing Normal University, and were conducted in compliance with European guidelines for the care and use of laboratory animals.

Data Availability The authors declare that [the/all other] data supporting the findings of this study are available within the article [and its supplementary information files].

Code Availability Software Used: ADF 2017.

Conflict of interest/Competing Interests No conflicts/competing interest.

\section{References}

1. Shiraishi Y, Sumiya S, Hirai T (2011) Highly sensitive cyanide anion detection with a coumarinspiropyran conjugate as a fluorescent receptor. Chem Commun 47:4953-4955. https://doi.org/10.1039/C1CC10467E

2. Kumar A, Vanitab V, Walia A, Chae PS, Kumar S (2020) Pyridoanthrone-based chromo-fluorogenic amphiphiles for selective $\mathrm{CN}^{-}$detection and their bioimaging application. Sens Actuator $\mathrm{B}$ Chem 304:127396. https://doi.org/10.1016/j.snb.2019.127396

3. Moriya F, Hashimoto Y (2001) Potential for error when assessing blood cyanide concentrations in fire victims. J For Sci 46:1421-1425 
4. Ravichandiran P, Czubara AB, Masłyk M, Bella AP, Johnson PM, Subramaniyan SA, Shim KS, Yoo DJ (2020) A phenoxazine-based fluorescent chemosensor for dual channel detection of $\mathrm{Cd}^{2+}$ and $\mathrm{CN}^{-}$ ions and its application to bio-imaging in live cells and zebrafish. Dyes Pigments 172:107828. https://doi.org/10.1016/j.dyepig.2019.107828

5. Wu H, Chen MM, Xu QQ, Zhang Y, Liu PP, Li WY, Fan SH (2019) Switching to a "turn-on" fluorescent probe for selective monitoring of cyanide in food samples and living systems. Chem Commun 55:15137-15140. https://doi.org/10.1039/C9CC07492A

6. Zhang J, Chai X, He XP, Kim HJ, Yoon J, Tian H (2019) Fluorogenic probes for diseaserelevant Enzymes. Chem Soc Rev 48:683-722. https://doi.org/10.1039/C7CS00907K

7. Li J, Cui Y, Bi C, Feng S, Yu F, Yuan E (2019) Oligo(ethylene glycol)-Functionalized Ratiometric Fluorescent Probe for the Detection of Hydrazine in Vitro and in Vivo. Anal Chem 91:7360-7365. https://doi.org/10.1021/acs.analchem.9b01223

8. Lindsay AE, O'Hare D (2006) The development of an electrochemical sensor for the determination of cyanide in physiological solutions. Anal Chim Acta 558:158-163. https://doi.org/10.1016/j.aca.2005.11.036

9. Zhou X, Nie J, Du B (2017) Functionalized ionic microgel sensor array for colorimetric detection nd discrimination of metal ions. ACS Appl Mater Interfaces 9:20913-20921. https://doi.org/10.1021/acsami.7b06337

10. Safavi A, Maleki N, Shahbaazi HR (2004) Indirect determination of cyanide ion and hydrogen cyanide by adsorptive stripping voltammetry at a mercury electrode. Anal Chim Acta 503:213-221. https://doi.org/10.1016/j.aca.2003.10.032

11. Nguyen VN, Kumar A, Lee MH, Yoon J (2020) Recent advances in biomedical applications of organic fluorescence materials with reduced singlet-triplet energy gaps. Coord Chem Rev 425:213545213569. https://doi.org/10.1016/j.ccr.2020.213545

12. Zhou JJ, Blanca DR, Daniel J, Seiichi U, Jin DY (2020) Advances and challenges for fluorescence nanothermometry. Nat Methods 17:967-980. https://doi.org/10.1038/s41592-020-0957-y

13. Liu HW, Chen LL, Xu CY, Li Z, Zhang HY, Zhang XB, Tan WH (2018) Recent progresses in smallmolecule enzymatic fluorescent probes for cancer imaging. Chem Soc Rev 47:7140-7180. https://doi.org/10.1039/c7cs00862g

14. Yin J, Hu Y, Yoon J (2015) Fluorescent probes and bioimaging: alkali metals, alkaline earth metals and pH. Chem Soc Rev 44:4619-4644. https://doi.org/10.1039/c4cs00275j

15. Gu KZ, Xu YS, Li H, Guo ZQ, Zhu SJ, Zhu SQ, Shi P, James TD, Tian H, Zhu WH (2016) Real-Time Tracking and In Vivo Visualization of $\beta$ Galactosidase Activity in Colorectal Tumor with a Ratiometric Near-Infrared Fluorescent Probe. J Am Chem Soc 138:5334-5340. https://doi.org/10.1021/jacs.6b01705

16. Yang XL, Yang YT, Zhou TT, Jin M, Jing XQ, Miao CH, Li W (2019) A mitochondria-targeted ratiometric fluorescent probe for detection of $\mathrm{SO}_{2}$ derivatives in living cells and in vivo. J Photochem Photobiol A 372:212-217. https://doi.org/10.1016/j.jphotochem.2018.12.020 
17. Liu Y, Feng GQ (2014) A visible light excitable colorimetric and fluorescent ESIPT probe for rapid and selective detection of hydrogen sulfide. Org Biomol Chem 12:438-445.

https://doi.org/10.1039/c3ob42052c

18. He YY, Li ZX, Shi BJ, An Z, Yu MM, Wei LH, Ni ZH (2017) A new near-infrared ratiometric fluorescent probe for hydrazine. RSC Adv 7:25634-25639. https://doi.org/10.1039/c7ra04270a

19. Qi SJ, Liu WM, Zhang PP, Wu JS, Zhang HY, Ren HH, Ge JC, Wang PF (2018) A colorimetric and ratiometric fluorescent probe for highly selective detection of glutathione in the mitochondria of living cells. Sens Actuator B Chem 270:459-465. https://doi.org/10.1016/j.snb.2018.05.017

20. Zhu YL, Wang KN, Song WH, Dong BL, Zhao SF, Guan RF, Li ZP, Sun YT, Cao DX, Lin WY (2019) A mitochondria-targeted ratiometric fluorescent probe for endogenous cyanide in biological samples. Sens Actuator B Chem 294:283-290. https://doi.org/10.1016/j.snb.2019.05.058

21. Luo J, Xie Z, Lam JWY, Cheng L, Tang BZ, Chen H, Qiu C, Kwok HS, Zhan X, Liu Y, Zhu D (2001) Aggregation-induced emission of 1-methyl-1,2,3,4,5-pentaphenylsilole. Chem Commun 1740-1741. https://doi.org/10.1039/b105159h

22. Yang J, Liu XL, Wang HL, Tan HQ, Xie XX, Zhang X, Liu CC, Qu X, Hu JL (2018) A turn-on near-infrared fluorescence probe with aggregation-induced emission based on dibenzo $[a, c]$ phenazine for detection of superoxide anions and its application in cell imaging. Analyst 143:1242-1249. https://doi.org/10.1039/c7an01860f

23. Lin MG, Huang J, Zeng F, Wu SZ (2019) A Fluorescent Probe with Aggregation-Induced Emission for Detecting Alkaline Phosphatase and Cell Imaging. Chem Asian J 14:802-808. https://doi.org/10.1002/asia.201801540

24. Nicol A, Qin W, Kwok RTK, Burkhartsmeyer JM, Zhu ZF, Su HF, Luo WW, Lam JWY, Qian J, Wong KS, Tang BZ (2017) Functionalized AIE nanoparticles with efficient deep-red emission, mitochondrial specificity, cancer cell selectivity and multiphoton susceptibility. Chem Sci 8:4634-4643. https://doi.org/10.1039/c7sc00908a

25. Ma LL, Leng TH, Wang K, Wang CY, Shen YJ, Zhu WH (2017) A coumarin-based fluorescent and colorimetric chemosensor for rapid detection of fluoride ion. Tetrahedron 73:1306-1310. https://doi.org/10.1016/j.tet.2017.01.034

26. He L, Xiong HQ, Wang BH, Zhang Y, Wang JP, Zhang HY, Li HP, Yang ZG, Song XZ (2020) Rational Design of a Two-Photon Ratiometric Fluorescent Probe for Hypochlorous Acid with a Large Stokes Shift. Anal Chem 92:11029-11034. https://doi.org/10.1021/acs.analchem.0c00030

27. Chen FZ, Han DM, Liu H, Wang SF, Li KB, Zhang SQ, Shi W (2018) A tri-site fluorescent probe for simultaneous sensing of hydrogen sulfide and glutathione and its bioimaging applications. Analyst 143:440-448. https://doi.org/10.1039/c7an01588g

28. Xu HK, Zhang HH, Liu G, Kong L, Zhu XJ, Tian XH, Zhang ZP, Zhang RL, Wu ZC, Tian YP, Zhou HP (2019) Coumarin-Based Fluorescent Probes for Super-resolution and Dynamic Tracking of Lipid Droplets. Anal Chem 91:977-982. https://doi.org/10.1021/acs.analchem.8b04079 
29. Gandioso A, Bresolí-Obach R, Nin-Hill A, Bosch M, Palau M, Galindo A, Contreras S, Rovira A, Rovira C, Nonell S, Marchán V (2018) Redesigning the Coumarin Scaffold into Small Bright Fluorophores with Far-Red to Near-Infrared Emission and Large Stokes Shifts Useful for Cell Imaging. J Org Chem 83:1185-1195. https://doi.org/10.1021/acs.joc.7b02660

30. Zhu JW, Ou HD, Xu NW, Deng W, Yao ZJ (2020) Ruthenium-based phosphorescent probe for selective and naked-eye detection of cyanide in aqueous media. Dyes Pigments 176:108196. https://doi.org/10.1016/j.dyepig.2020.108196

31. Sun GC, Chen W, Liu Y, Jin X, Zhang ZY, Su JH (2020) A novel colorimetric and fluorometric probe for the detection of $\mathrm{CN}^{-}$with high selectivity in aqueous media. Dyes Pigments 176:108224. https://doi.org/10.1016/j.dyepig.2020.108224

32. Wen XY, Yan L, Fan ZF (2020) A novel AIE active NIR fluorophore based triphenylamine for sensing of $\mathrm{Hg}^{2+}$ and $\mathrm{CN}^{-}$and its multiple application. Spectrochim Acta Part A 241:118664-118672. https://doi.org/10.1016/j.saa.2020.118664

\section{Figures}
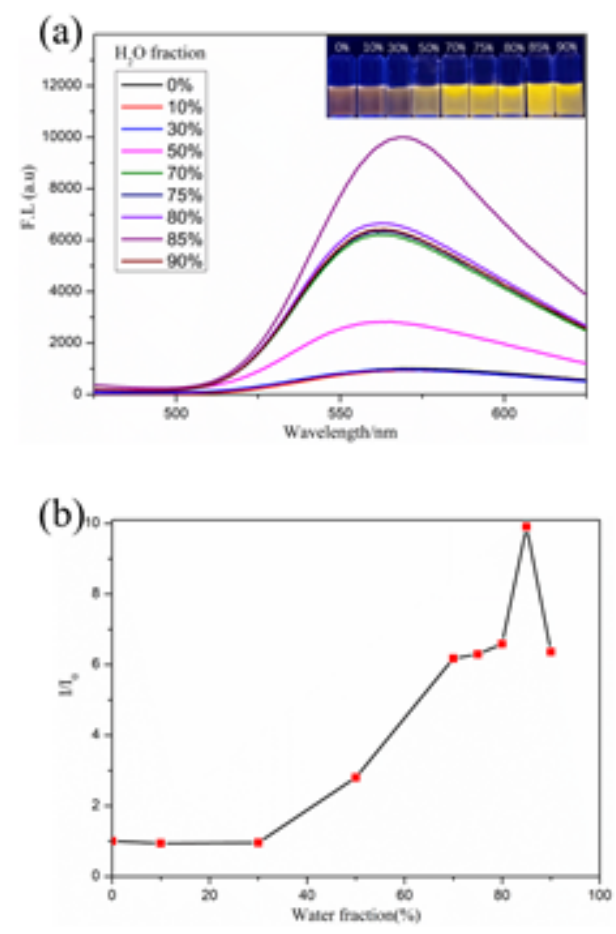

\section{Figure 1}

a Fluorescence spectra of probe $\mathrm{C}-\mathrm{BH}$ in $\mathrm{DMSO} / \mathrm{H} 2 \mathrm{O}$ solutions with different water fractions (inset was the color change of probe with various ratio water). b Plot of relative peak intensity $(1 / 10)$ and ratio of water. 

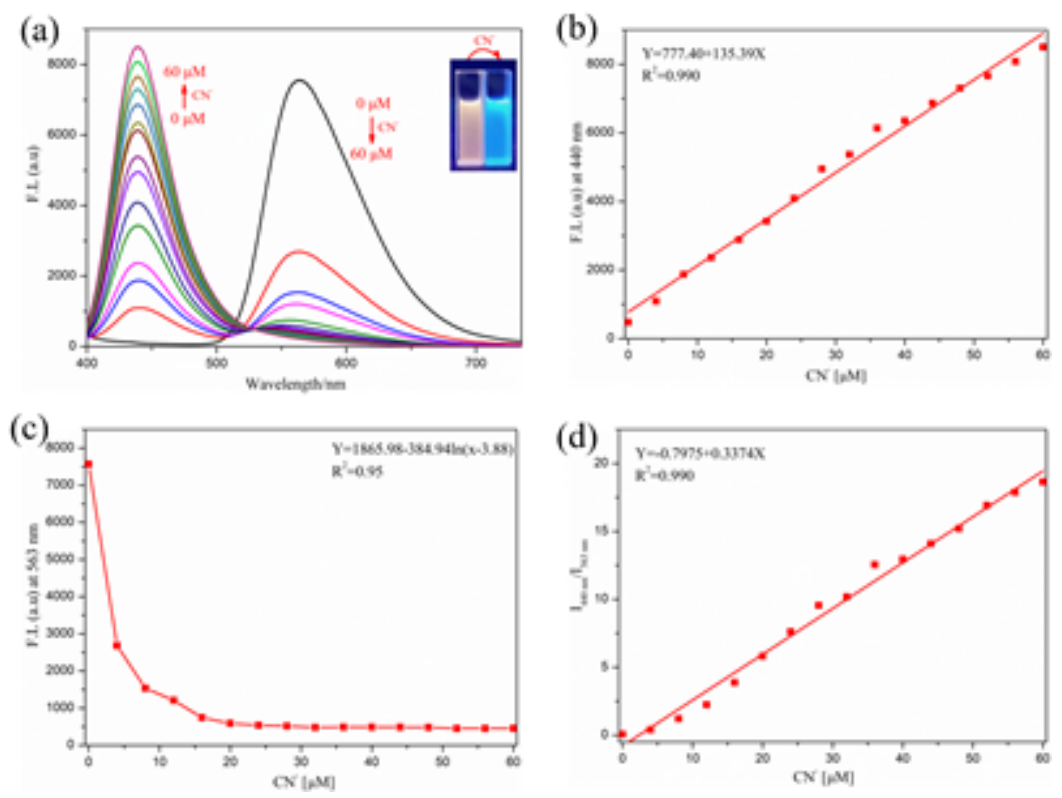

Figure 2

a Changes of fluorescence spectra of probe C-BH $(10 \mu \mathrm{M})$ with titration of different concentration of $\mathrm{CN}$ $(0-60 \mu \mathrm{M})$. b the relationship of I440nm versus the concentration of $\mathrm{CN}$ - over the range from 0 to $60 \mu \mathrm{M}$. C the relationship of $1563 \mathrm{~nm}$ versus the concentration of $\mathrm{CN}$ - over the range from 0 to $60 \mu \mathrm{M}$. $\mathrm{d}$ the relationship of $1440 \mathrm{~nm} / 1563 \mathrm{~nm}$ versus the concentration of $\mathrm{CN}$ - over the range from 0 to $60 \mu \mathrm{M}$.

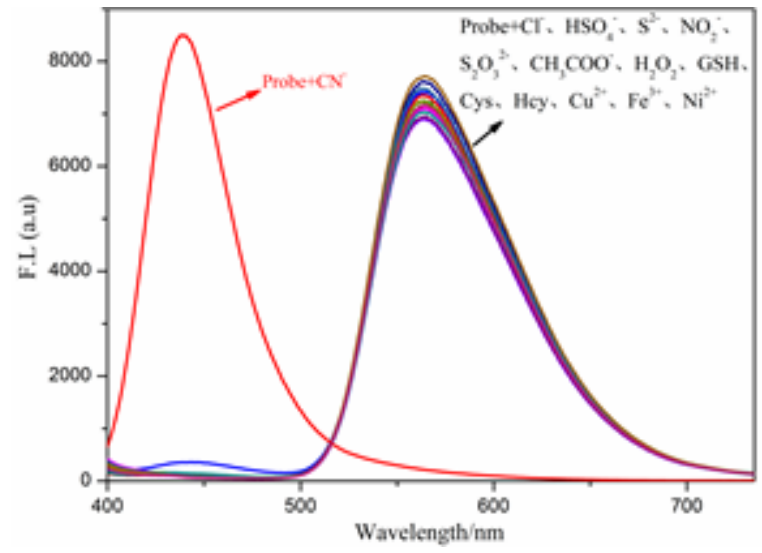

Figure 3

The change of fluorescence spectrum of $\mathrm{C}-\mathrm{BH}$ in the existence of various species $(60 \mu \mathrm{M})$. 
(a)

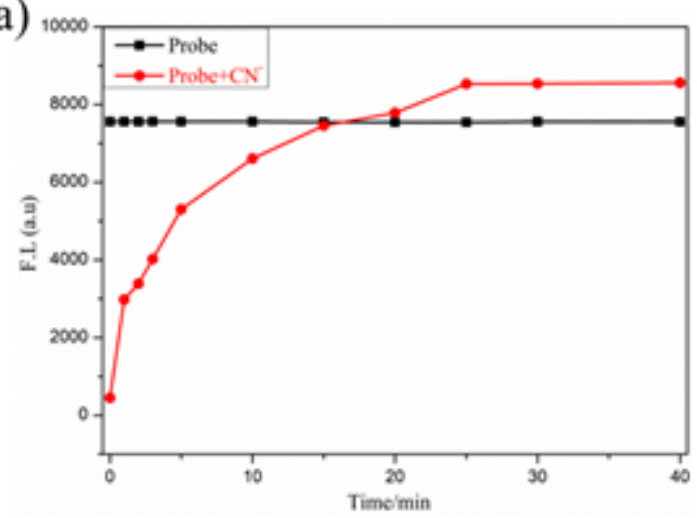

(b)

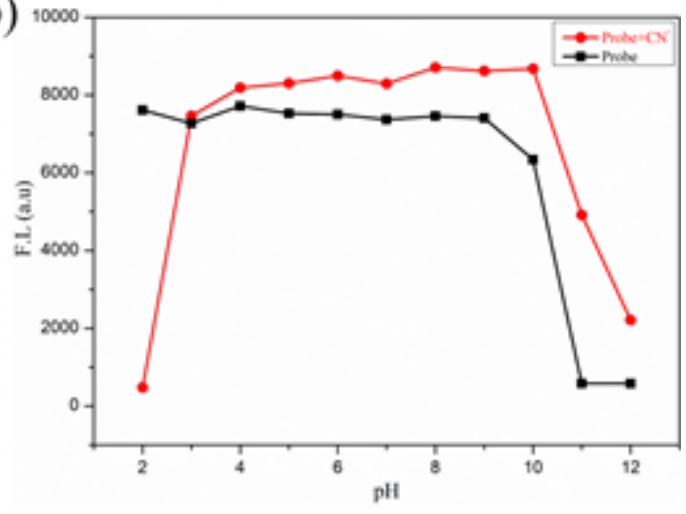

Figure 4

a The changes of fluorescence intensities of probe $\mathrm{C}-\mathrm{BH}$ over time in the presence of $\mathrm{CN}-$. b fluorescence intensity changes of the probe $\mathrm{C}-\mathrm{BH}(10 \mu \mathrm{M})$ with and without $\mathrm{CN}-(60 \mu \mathrm{M})$ under different $\mathrm{pH}$ conditions.

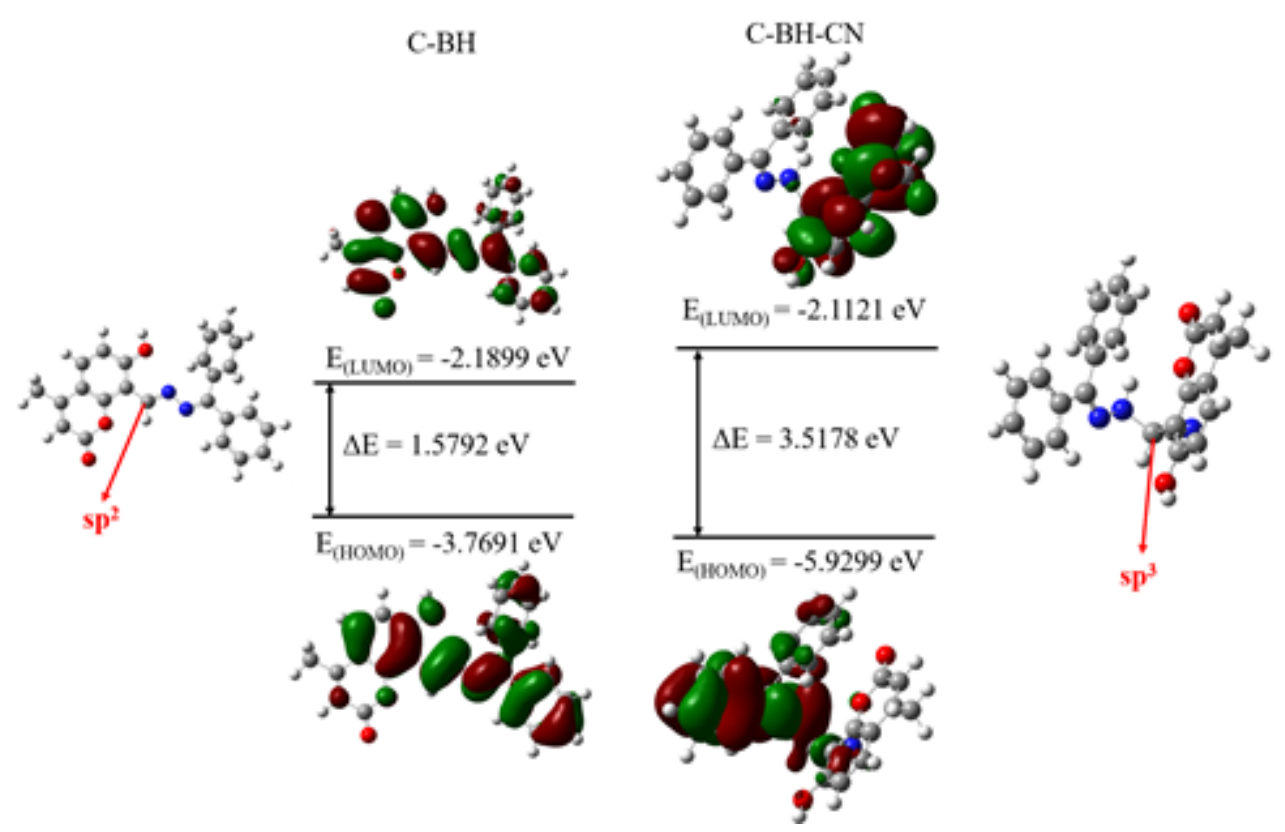

Figure 5

Energy-minimized structures and HOMO/ LOMO orbitals of C-BH and C-BH-CN by DFT calculation. 


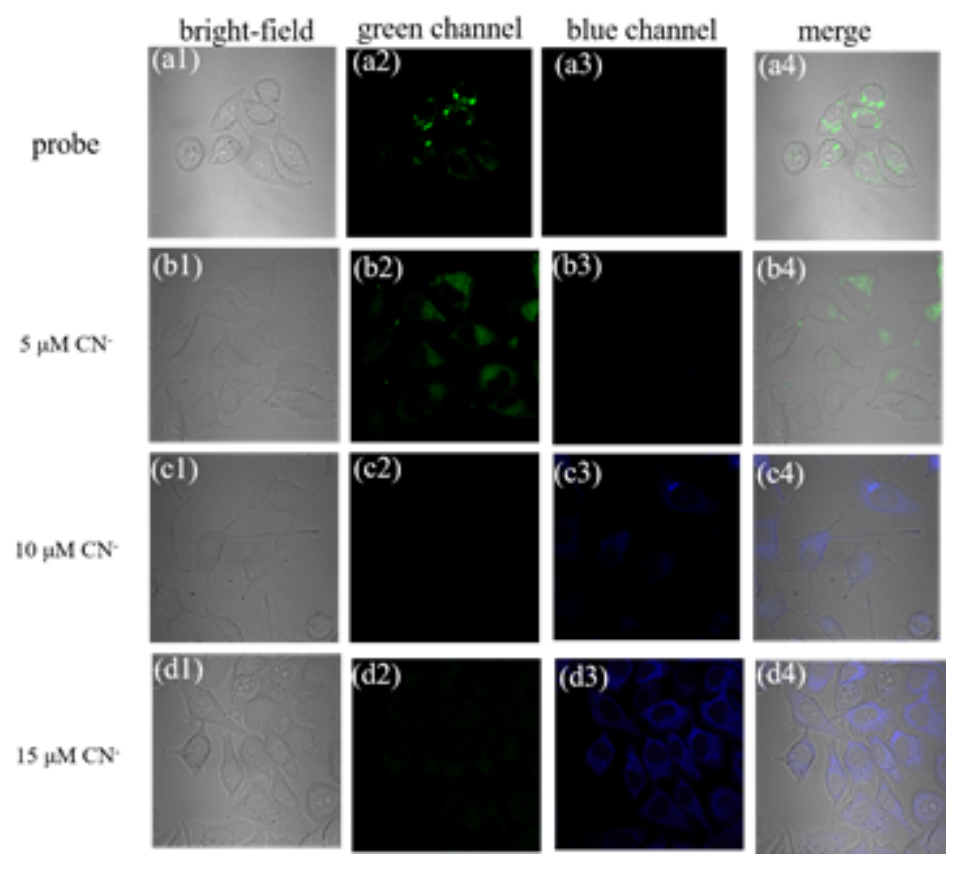

\section{Figure 6}

Bright field, green channel, blue channel, and merged image of HeLa cells with probe C-BH cells (a1-a4), HeLa cells with probe C-BH and various concentration of CN- (b1-b4, c1-c4, and d1-d4). Scale bar=20 $\mu \mathrm{m}$.

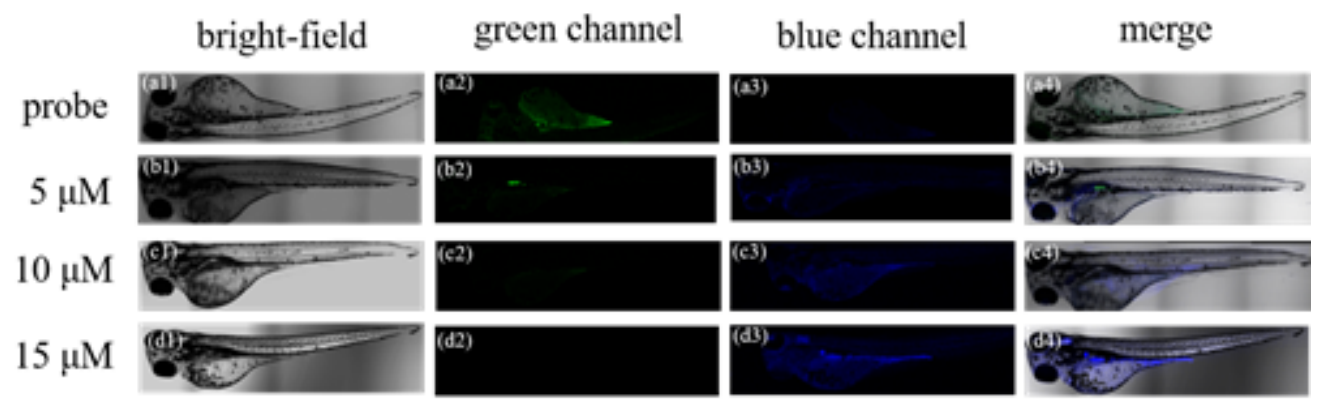

\section{Figure 7}

Bright field, green channel, blue channel, and merged image of zebrafish with probe C-BH cells (a1-a4), zebrafish with probe $\mathrm{C}-\mathrm{BH}$ and various concentration of $\mathrm{CN}-(\mathrm{b} 1-\mathrm{b} 4, \mathrm{c} 1-\mathrm{c} 4$, and d1-d4). All scale bars $=100$ $\mu \mathrm{m}$.

\section{Supplementary Files}

This is a list of supplementary files associated with this preprint. Click to download.

- Scheme01.png

- SupplementaryMaterial.docx 